\title{
Implementation Evaluation Based Learning Curriculum 2013 Implementation of Activity Based on Learning Tematik in Elementary Schools in Labuhanbatu District
}

\author{
Wan Sri Putri Saadah ${ }^{1}$, Rahmad Husein ${ }^{2}$, Siti Julaeha ${ }^{3}$ \\ ${ }^{1,3}$ Universitas Terbuka, Indonesia \\ ${ }^{2}$ Universitas Negeri Medan, Indonesia \\ wansri.saadah@gmail.com
}

\begin{abstract}
This research is a descriptive qualitative research which aims to describe the implementation of the 2013 Curriculum in the learning process in terms of learning planning, learning implementation, and learning evaluation. The population and sample in this study were teachers and students of Public Elementary Schools throughout Labuhanbatu Regency who have implemented the 2013 Curriculum since its inception in 2013, namely SD Negeri 28 Bilah Barat, SD Negeri 01 Bilah Barat, SD Negeri 08 Rantau Selatan, SD Negeri 11 Rantau Selatan, SD Negeri 15 Rantau Utara, and SD Negeri 06 Rantau Utara. The samples in this study were 46 for teacher respondents and 182 for student respondents at SD Negeri Labuhanbatu Regency. The instrument in this study was a semi-open questionnaire containing statement items, and the variable questionnaire was measured using a Likert scale. The results showed that the teacher's understanding of 2013 Curriculum-based learning planning was in the quite good category, with an average percentage of $74.72 \%$. This is evidenced by the teacher's ability to compile a syllabus and lesson plans. The teacher's understanding of the implementation of curriculum-based learning in 2013 is in the good category, with an average percentage value of $76.13 \%$. This can be seen from the teacher's ability in terms of class mastery. The teacher's understanding of the 2013 Curriculum-based learning evaluation is in the quite good category, with an average percentage of $73.5 \%$. This can be proven by the teacher's ability to take an authentic approach. Meanwhile, the students' responses about the implementation of 2013 Curriculum-based learning carried out by the teacher showed a fairly good category, with an average percentage of $72.75 \%$. For students' perceptions about the evaluation or assessment of learning based on the 2013 Curriculum conducted by the teacher, it is in the quite good category, with an average percentage of $73 \%$.
\end{abstract}

Keywords

curriculum 2013; the process of learning; teachers and elementary school students

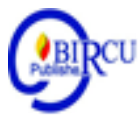

\section{Introduction}

Education is a long-term investment that requires considerable effort and funds. This is recognized by all people or a nation for the continuity of its future. Likewise, Indonesia has high hopes for educators in the future development of this nation, because from there the young shoots of the nation's hope as the next generation are formed. Based on Law Number 20 of 2003 concerning the National Education System, education is a conscious and planned effort to create a learning atmosphere and is a learning process in such a way 
that students can develop their potential actively so that they have self-control, intelligence, skills in society, religious spiritual strength, personality, and noble character. Without education, humans cannot grow up to be human beings who are good in mind, mind and socially.

Educational activities can take place within the family, school, and community. Education can take place anywhere, anytime, and in various ways. In the family environment, the interaction between parents and students is an educational interaction without a written planning or curriculum so that the family environment is included in informal education. Meanwhile, in the community, there is also formal education such as courses, tutoring which also has a varied curriculum, but education experts instill this education with the term out of school education. Fatmawati (2019) said that every school is required to have a curriculum, both formal and informal.

The curriculum aims to develop attitudes, knowledge and skills that instill Indonesian culture as the basis for the development of Indonesian education that is capable and useful for developing the quality of Indonesian people. The curriculum as a set of educational plans needs to be developed dynamically in accordance with the demands and changes that occur in society. The government has implemented a new curriculum called Curriculum 2013 in several target schools as a pilot project. The presence of the 2013 Curriculum as a new curriculum in the world of national education is expected to further enhance the previous curriculum, namely KTSP (Education Unit Level Curriculum). According to Fatmawati (2019) there are several curricular standards that must be fulfilled, including the objectives, process, content, and most importantly evaluation of learning.

This curriculum evaluation can cover the entire curriculum or each curriculum component such as the objectives, content, or learning methods in the curriculum. In simple terms, curriculum evaluation can be equated with research because curriculum evaluation uses systematic research, applying scientific procedures and research methods. Evaluation aims to collect, analyze and present data for decision making materials regarding the curriculum whether to be revised or replaced.

Evaluation of 2013 Curriculum-Based Learning Implementation In terms of Thematic Learning Activities at SD in Labuhanbatu Regency, teachers play an important role, both in planning, implementing, and developing curriculum in their class. Based on Law Number 14 of 2005, teachers are professional educators with the main task of educating, teaching, guiding, directing, training, assessing, and evaluating students in early childhood education through formal education, basic education, and secondary education.

The stages of implementing the curriculum launched by the government began in July 2015/2016, namely as many as 6\% of schools throughout Indonesia implemented the 2013 Curriculum. In July 2016/2017 around 25\% of schools implemented the 2013 Curriculum. In July 2017/2018 around $60 \%$ of schools throughout Indonesia have implemented the 2013 Curriculum. In 2018/2019, all schools have implemented the 2013 Curriculum until now.

The orientation of the 2013 curriculum is an increase and balance between the competence of attitudes, skills and knowledge. This is in line with the mandate of Law Number 20 of 2003 as stated in the explanation of Article 35, namely that the competence of graduates is a qualification of graduation abilities which includes attitudes, knowledge, and skills in accordance with agreed national standards. This is also in line with the development of a Competency-Based Curriculum that was initiated in 2004 which includes competency attitudes, knowledge and skills in an integrated manner. 
The research results of the Labuhanbatu Regency Education Office stated that there was an increase in children's learning outcomes after the implementation of the 2013 Curriculum as a whole in Labuhanbatu district after evaluating it for 3 consecutive years by providing training to all teachers in turn at both the elementary and middle school levels.

The results of Imam Dwi Upayanto's (2017) research entitled 'Implementation of 2013 Curriculum Learning Process at SD Negeri 4 Krandegan' states that the implementation of the 2013 Curriculum learning process at SD Negeri 4 Krandegan, Banjarnegara District, Banjarnegara Regency is as follows. 1) Planning has been running according to the rules of the 2013 Curriculum listed in Permendikbud Number 57 of 2014, but there are still difficulties in terms of preparing learning materials and media; 2) The implementation of the learning process in the classroom is in accordance with the RPP, but there are still obstacles in time management and learning media; 3) The assessment has not gone well because in the implementation it has used thematic, but in the assessment the teacher must make an assessment per subject.

Researchers are interested in conducting research on curriculum evaluation, namely by looking at the curriculum changes carried out by the government in relation to the implementation of classroom learning by referring to the Learning Implementation Plan (RPP) and the application of the teaching and learning process. In addition, the readiness of teachers to follow the 2013 curriculum, what obstacles are faced by teachers in the 2013 curriculum and the means that support the 2013 curriculum in the learning process.

\section{Review of Literatures}

\subsection{Policy Implementation}

Browne \& Wildavsky (in Firdiani, 2018: 19) states that implementation is the expansion of activities that are mutually adapting. Schubert (in Firdiani, 2018: 19) states' Implementation is an engineering system. 'Furthermore, Firdiani (2018: 19) states that' Implementation is an activity that is planned and carried out seriously based on certain norm references to achieve activity objectives.

According to Ririn (2020) Education in Indonesia is a process of developing a society and government that is carried out consciously and responsibly for the survival and life of the next generation. According to Winarto (in Ali, 2017: 51) 'Implementation is the provision of means to carry out something that has an impact or consequence.' Meanwhile, according to Van Meter and Van Horn (in Uddin \& Sobirin, 2017: 121) 'Implementation is actions which is done either by individuals or groups that are directed at the achievement of predetermined goals. Based on the above opinion, it can be concluded that implementation is the application of an activity in order to achieve an activity goal.

According to Rajasekar (in Marlizar, 2018: 98) there are 4 factors that influence the implementation of (a) leadership style, (b) organizational structure, (c) organizational culture, (d) human resources, and (d) technology. In line with that Edward (in Lwihpakerti, M. and Purnaweni, H., 2016: 3) the factors that support implementation are (a) communication, (b) resources, and (c) organizational structure. Implementation of the 2013 Curriculum is most difficult at the level of Elementary Education. Thus, at the SD level what is being taught is no longer a subject, but a theme. Each lesson content has been themed with certain themes. Each theme, sub-theme, and learning consists of several basic competencies from several subject matter, namely Indonesian, mathematics, Civics, SBdP, Physical Education (grades 1-3), as well as Social Sciences and Science (for grades 4-6). At the SMP and SMA levels, it remains subject-based. 


\subsection{Curriculum 2013}

Fatmawati (2019) argues that the curriculum is a plan that provides guidelines or guidelines in the process of teaching and learning activities. According to Shobirin (2016: 35) Curriculum 2013 is an improvement of KTSP, which aims to prepare Indonesian people to have the ability to live as individuals and citizens who are faithful, productive, creative, innovative, and affective and able to contribute to the life of the community, nation, state and world civilization.

The Ministry of Education and Culture (2013) states that 'The SD / MI curriculum uses an integrative thematic learning approach from grade I to grade VI. Integrative thematic learning is a learning approach that integrates various competencies from various subjects into various themes. The integration is carried out in two ways, namely the integration of attitudes, skills and knowledge in the learning process and the integration of various related basic concepts.

The theme knits the meanings of various basic concepts so that students do not partially learn basic concepts. Thus, learning provides complete meaning to students as reflected in the various available themes. Curriculum socialization needs to be done to various parties involved in its implementation, as well as to all school members, even the community and parents of students (Mulyasa, 2017). According to Sukirman and Dadang (2015: 1.7) the curriculum as an educational tool can be grouped into four functions as follows:

\section{a. The Curriculum Functions as a Cognitive Process}

As a cognitive process, the curriculum is seen as a tool for developing students' intellectual abilities, namely developing thinking skills to face and solve the problems to be faced.

\section{b. The Function of the Curriculum as a Self-Actualization Process}

As a student self-actualization process, the curriculum is a tool to facilitate students so that they can grow and develop according to their potential, interests and talents so that each student can get to know him and grow and develop as himself.

\section{c. Curriculum Function as Social Reconstruction Process}

As a process of social reconstruction, the curriculum is seen as a tool to equip students with the ability to become members of society who not only accept or adapt to existing 'life', but also innovatively and creatively develop life in a more productive and quality direction.

\section{d. The Function of the Curriculum as an Academic Program}

As an academic program, the curriculum is seen as a learning tool and companion, where from the learning activities programmed by the curriculum students can gain knowledge which is expected to equip the ability to "live" in the era they are in.

\subsection{Thematic Learning Curriculum 2013}

According to Musfiqon and Nurdyansyah (2015: 121), 'Thematic learning is learning by integrating the material of several subjects with one theme / topic of discussion.' According to Sutirjo and Mamik (in Musfiqon and Nurdyansyah, 2015: 121), 'Thematic learning is an effort to integrate knowledge, skills, values, or learning attitudes, as well as creative thinking using specific themes. 
Simorangkir (2019) states that Thematic learning is learning that is useful, interesting, meaningful, and appropriate for students in early primary school (SD) classes. The teacher must be creative in teaching, various approaches in learning need to be considered by the teacher so that learning can proceed in accordance with the objectives to be achieved.

According to Syakur (2017: 4), 'Thematic learning is integrated learning that uses themes to link several subjects so that it can provide meaningful experiences to students.' According to Dewey (in Malawi, Kadarwati, and Dayu (2019: 1), "Integrated thematic learning is an approach to developing students' abilities in knowledge formation based on interactions with the environment and experiences in their lives.'According to Malawi, Kadarwati, and Dayu (2019: 2),' integrated thematic learning is one of the learning models that use themes to link several subjects so that they can provide meaningful experiences for students.

Based on the above opinion, it can be concluded that thematic learning is learning that combines several subject matter into a theme with the aim of developing student abilities as a whole and providing meaningful experiences.

Thematic learning is one of the integrated learning models (integrated instruction) which is a learning system that emphasizes students both individually and in groups, actively exploring and discovering scientific concepts and principles in a holistic, meaningful and authentic manner, so that in activities student learning is actively directed to be involved. This is what underlies the formation of thematic learning and eliminates and rejects the process of practice / memorization as a basis for instilling and shaping knowledge and intellectual structures in primary school children holistically.

\subsection{Assessment in the 2013 Curriculum \\ a. Attitude Assessment}

Attitude assessment is intended as an assessment of the behavior of students in the learning process both in curricular and extracurricular activities, which include spiritual and social attitudes. Attitude assessment has different characteristics from the assessment of knowledge and skills, so the assessment techniques used are also different. In this case, attitude assessment is more aimed at fostering behavior according to character in the context of forming the character of students in accordance with the learning process.

\section{b. Knowledge Assessment}

Knowledge assessment (KI-3) is carried out by measuring the mastery of students which includes factual, conceptual, and procedural knowledge at various levels of thought processes. Assessment in the learning process serves as a tool to detect learning difficulties (assessment as learning), assessment as a learning process (assessment for learning), and assessment as a tool to measure achievement in the learning process (assessment of learning). Through this assessment, students are expected to master the expected competencies. For this reason, various assessment techniques are used according to the competencies to be assessed, namely written, oral, and assignments. The knowledge assessment procedure starts from the preparation of planning, developing assessment instruments, implementing the assessment, processing and reporting, and utilizing the results of the assessment. 


\section{c. Skills Assessment}

According to Sugiharto (2020) education is one of the efforts to improve the ability of human intelligence, thus he is able to improve the quality of his life. So, to create the highest quality of human resources, education is becoming an important factor to be considered. The importance of education is also reflected at MPR No. II/MPR/1993 which states that the national education aims to improve the quality of Indonesia people that is religious people, and pious to God Almighty, noble character, has high personality, discipline, work hard, responsible, independent, smart, healthy, physically and mentally healthy.

Skills assessment is carried out by identifying basic competency characteristics of skills aspects to determine the appropriate assessment technique. Not all basic competencies can be measured by performance appraisal, project appraisal or portfolio. The determination of the assessment technique is based on the characteristics of the skills competency to be measured. Skills assessment is intended to determine students' mastery of knowledge to recognize and solve problems in real life (real world). Assessment of skills using numbers with a score range of 0 to 100 and a description.

\section{IIII. Research Method}

This research is a qualitative research approach and the type of research is descriptive analysis. Sugiyono (2016:9). The qualitative research method is research used to examine the condition of natural objects, researchers are assigned as research actors, and the results of qualitative research emphasize generalization. Data collection techniques in this study were carried out by observation and interviews.

Salim \& Syahrum (2017:114) say that observations are made to see the object to be studied, the observer acts as an observer who only observes and does not participate in the subject's activities. Salim and Syahrum (2017:119) Bogan and Biklen say that an interview is a conversation between two or more people directed by someone with the intention of obtaining certain information. The data analysis used in this study was Miels and Huberman's analysis. Miles and Huberman in Emzir (2016: 129) there are 3 steps in analyzing them including; data reduction, data presentation and conclusion and verification. And the validity of the data is obtained by using Credibility, Transferability, Dependability, and Confirmability techniques.

This research was conducted in SD Negeri taken in three sub-districts in Labuhanbatu Regency which have implemented the 2013 Curriculum. The research subjects were 3 (three) Districts in Labuhanbatu Regency, totaling 81 schools. Data collection techniques in the form of observation and interviews.

\section{Results and Discussion}

\subsection{Results}

\section{a. Thematic Learning Planning in Terms of the Teacher}

Thematic learning planning includes the preparation of thematic Learning Implementation Plans and preparation of media and learning resources (in this case the media used are laptops, workbooks/Student Activity Sheets (LKS), text books, recordings, radio and television broadcasts, and use of LCD), learning assessment tools, and learning scenarios. 


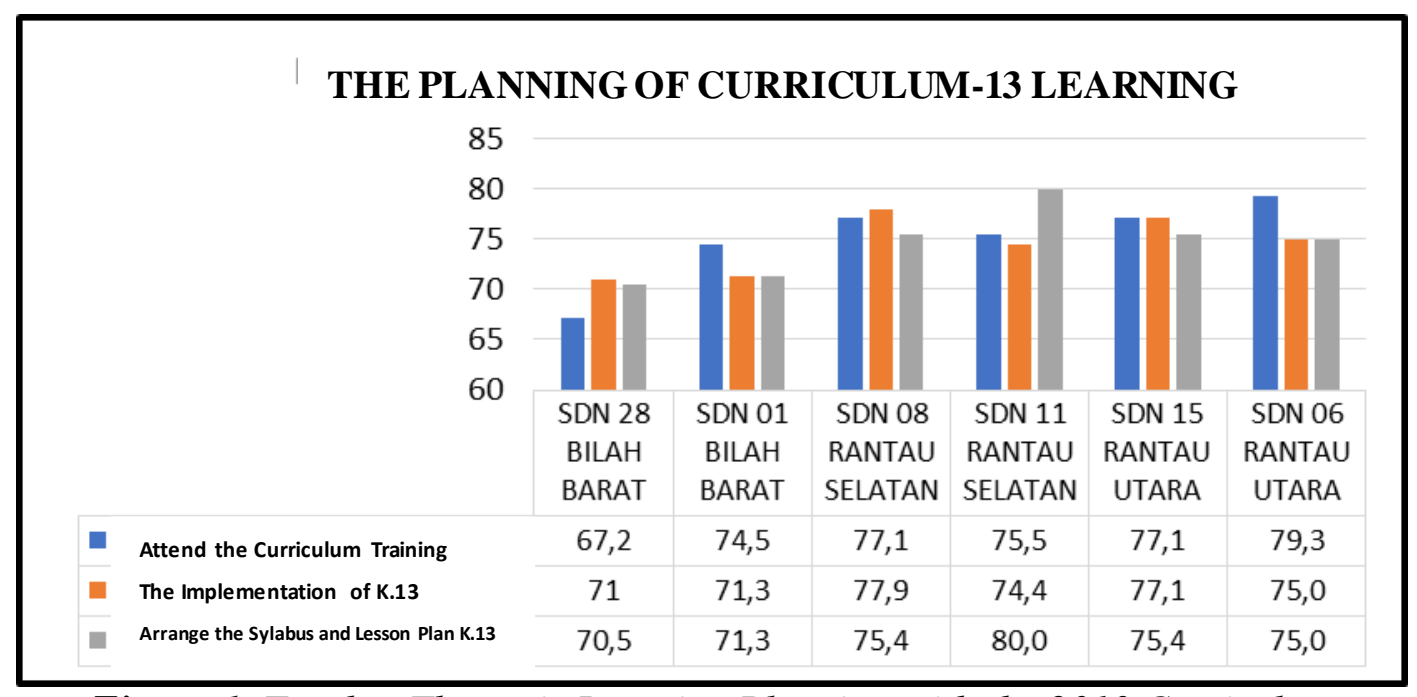

Figure 1. Teacher Thematic Learning Planning with the 2013 Curriculum

Based on Figure 1, the implementation of the 2013 Curriculum is in the quite good category, with an average percentage of $74.72 \%$. This means that the teacher has a good understanding in planning thematic learning according to the 2013 Curriculum.

\section{b. Implementation of Thematic Learning}

1. Implementation of Thematic Learning in Terms of the Teacher

The thematic learning implementation studied includes the implementation of learning in six State Elementary Schools throughout the Regency which have implemented the 2013 Curriculum since July 2013, namely SD Negeri 28 Bilah Barat, SD Negeri 01 Bilah Barat, SD Negeri 08 Rantau Selatan, SD Negeri 11 Rantau Selatan, SD Negeri 15 Rantau Utara, and SD Negeri 06 Rantau Utara. The results of the variable analysis of the implementation of thematic learning in six schools throughout Labuhanbatu Regency are described in Figure 2 following.

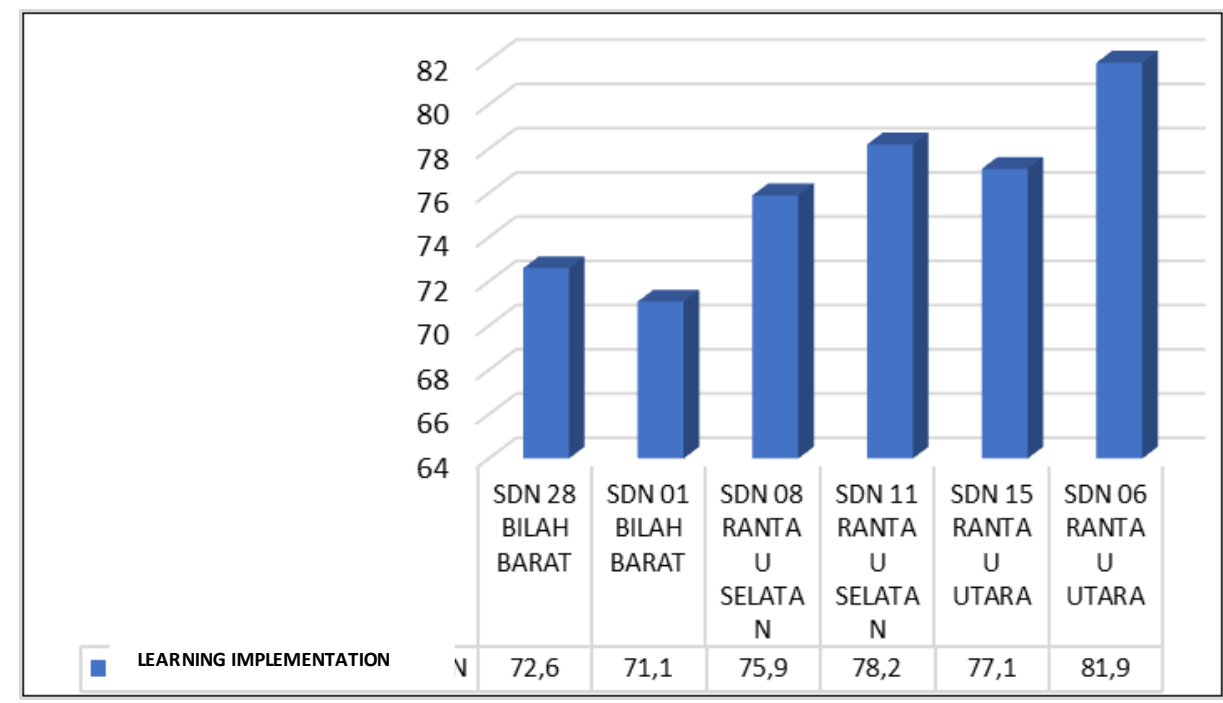

Figure 2. Implementation of Teacher Thematic Learning with the 2013 Curriculum 
Based on the picture above, it is explained that the percentage score and the comparison of scores in each school regarding the understanding of teachers in implementing thematic learning in accordance with the 2013 Curriculum are in the good category, with an average percentage value of $76.13 \%$. This means that the teacher's understanding is very good in implementing thematic learning in accordance with the 2013 Curriculum.

2. Thematic Learning Implementation in Terms of Students

Students' perceptions or responses to the implementation of the 2013 Curriculum in six State Elementary Schools in Labuhan Batu Regency that implement the 2013 Curriculum are presented in Figure 3 as follows.

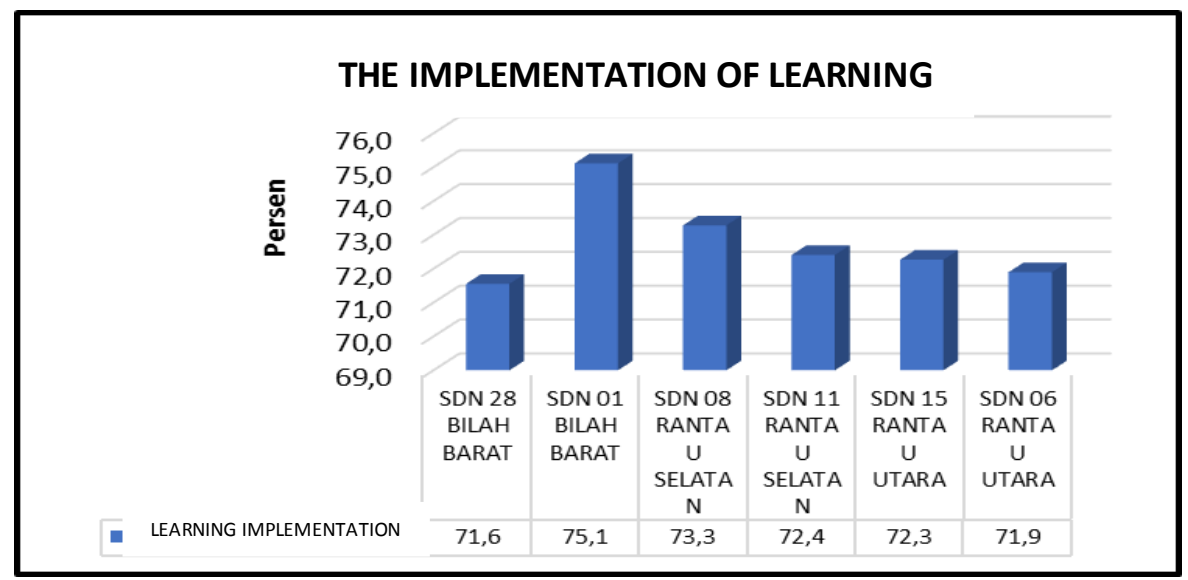

Figure 3. Implementation of Student Thematic Learning with the 2013 Curriculum

Based on the explanation in Figure 4, it is explained that the percentage and comparison of scores about student responses to the implementation of thematic learning based on the 2013 Curriculum are in the quite good category, with an average percentage of $72.75 \%$.

\section{c. Results of Thematic Learning Implementation}

1. Results of Thematic Learning Implementation in Terms of the Teacher

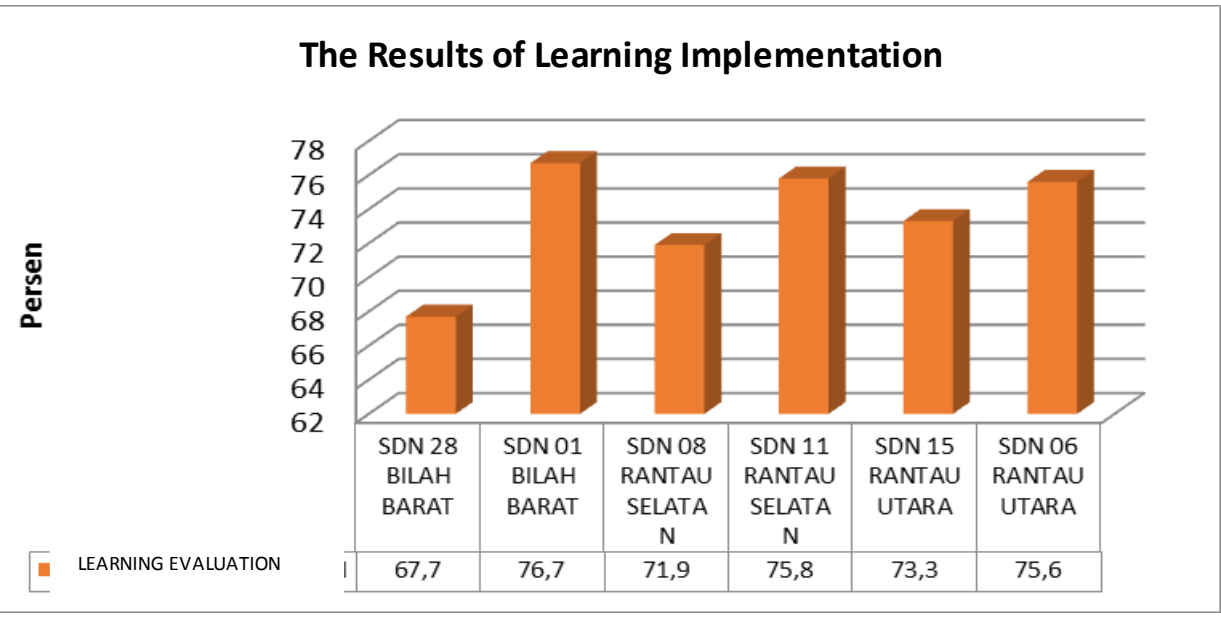

Figure 4. The Results of the Implementation of Teacher Thematic Learning in Accordance with the 2013 Curriculum 
The picture above shows the percentage score and the comparison of scores in each school. The teacher's understanding in carrying out the process of implementing thematic learning results in accordance with the implementation of the 2013 Curriculum is in the quite good category, with an average percentage of $73.5 \%$. Thus it can be interpreted that the teacher's understanding is good in carrying out the results of implementing thematic learning in accordance with the 2013 Curriculum.

\section{d. Results of Thematic Learning Implementation in Terms of Students}

The results of the implementation of thematic learning were analyzed from student respondents at six State Elementary Schools throughout Labuhan Batu Regency, as shown in Figure 5 as follows.

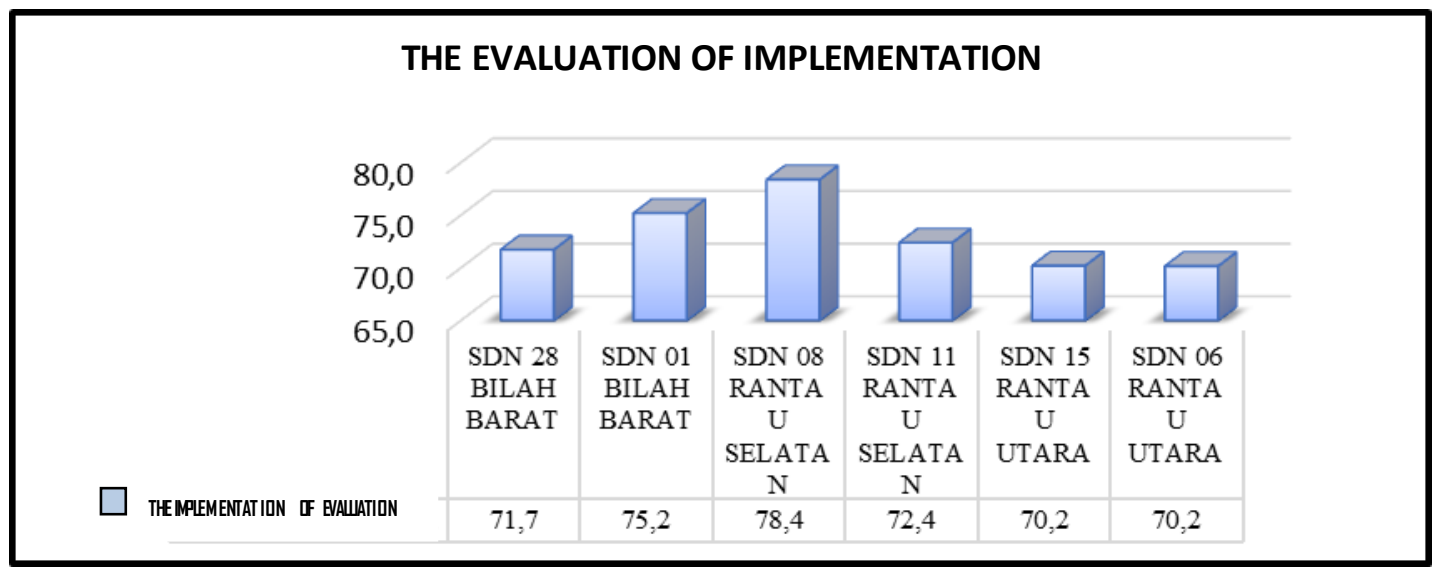

Figure 5. The Results of the Implementation of Student Thematic Learning with the 2013 Curriculum

Based on the explanation in Figure 5 above, it is explained that the percentage score of student responses to the results of implementing thematic learning based on the 2013 Curriculum is in the quite good category, with an average percentage of $73 \%$. This means that teachers are good at learning according to student responses in the classroom.

\subsection{Discussion}

\section{a. Thematic Learning Planning}

Thematic learning planning is designed in the form of a syllabus and a Thematic Learning Implementation Plan (Thematic RPP) which refers to the Content Standards. Thematic learning planning includes preparation of thematic learning implementation plans and preparation of learning media and resources, learning assessment tools, and learning scenarios. Thematic learning planning in this research is outlined in several indicators which are the subject of discussion of thematic learning planning conducted by elementary school teachers in Labuhan Batu Regency.

\section{b. Implementation of Thematic Learning}

The implementation of thematic learning is not only viewed from the teacher, but also in terms of students or student responses. The findings of research on student responses to the implementation of thematic learning at Public Elementary Schools in Labuhan Batu Regency show that the student response is quite good about the 
implementation of thematic learning based on the 2013 Curriculum carried out by teachers in the classroom. This can be seen from the activeness of students, namely.

1) Students are quite interested in participating in learning activities and pay attention to the teacher when delivering Curriculum 2013 learning material.

2) Students are quite easy to understand the material presented by the teacher.

3) Students are quite good at making observations or observations during learning, the teacher provides opportunities for students to observe in the 2013 Curriculum-based learning process.

4) The media used by the teacher in this lesson is enough to help students understand the tasks that must be done and make good use of the media.

5) Students are quite active in conducting questioning activities in the 2013 Curriculumbased learning process,

6) Students are quite active in discussing activities and collecting information in the learning process based on the 2013 Curriculum,

7) Students are quite active in processing information activities in the 2013 Curriculumbased learning process, and

8) Students are good enough in concluding learning material delivered by the teacher and working together in groups.

\section{c. The Results of Implementing Thematic Learning}

Learning evaluation is an assessment process that functions to assess relevant elements in the sequence of planning and implementing teaching. The results of implementing thematic learning are a component in the teaching system that functions to evaluate the learning process. The findings in this study indicate that teachers are good at conducting the results of the 2013 curriculum-based learning implementation evaluation in terms of thematic learning activities at SD throughout Labuhanbatu Regency. This can be seen from the teacher both in taking an authentic approach and in assessing students on the affective aspects which include observation, self-assessment, peer-to-peer assessments and teacher journals.

In addition to being carried out by the teacher, evaluation or assessment of learning, students also carry out learning assessments by responding to the implementation of thematic learning carried out by the teacher in the classroom. The results of the implementation of thematic learning are also carried out to find out about the implementation of thematic learning is going well or not. In terms of students' perceptions, the research findings indicate that the teacher did the results of implementing thematic learning in terms of students well. This can be seen from indicators 1) The teacher gives assignments or homework and the teacher, 2) The teacher gives questions and tells the value of the assignment / test / quiz, 3) The student is very proud of the results of the scores obtained, 4) the teacher is quite good at giving feedback to students on the results of implementing thematic learning based on the 2013 Curriculum, and 3) the teacher is quite good at providing remedials to students, and 5) Students are quite good at enjoying togetherness and cooperation in completion.

\section{Conclusion}

The results of the evaluation of the implementation of the 2013 Curriculum-based learning in Public Elementary Schools in Labuhanbatu Regency are in the quite good category, with a percentage value of $73.5 \%$. This can be proven by the teacher's ability to take an authentic approach. Meanwhile, students' perceptions about the evaluation or 
assessment of learning based on the 2013 Curriculum conducted by Thematic teachers at Public Elementary Schools in Labuhanbatu Regency fall into the fairly good category, with a percentage value of $73 \%$. This can be proven from the teacher doing the results of implementing thematic learning based on the 2013 Curriculum, the teacher is quite good at providing feedback to students in the results of implementing thematic learning based on the 2013 Curriculum and providing remedials to students.

\section{References}

Ali, Muhammad. (2017). Kebijakan Pendidikan Menengah Dalam Perspektif governance di Indonesia. Rantauprapat : UB Press

Direktorat Jenderal Pendidikan Dasar dan Menengah dan Badan Penelitian dan Pengembangan (Pusat Penilaian Pendidikan dan Pusat Kurikulum dan Perbukuan). (2015). Buku Panduan Penilaian Pada Sekolah Dasar. Jakarta: Kementerian Pendidikan dan Kebudayaan RI.

Emzir. 2016. Metodologi Penelitian Kualitatif Ananlisis Data. Jakarta: PT Raja Grafindo Persada

Fatmawati .2019. Curriculum Implementation of Sou (school of universe) in Bogor. Budapest International Research and Critics Institute (BIRCI-Journal). Vol 2. No 2

Firdiyani, Arinda. (2018). Implementasi Manajemen Berbasis Sekolah dalam Meningkatkan Prestasi Belajar Siswa. Yogyakarta : CV. Gre. publishing

Imam Dwi Upayanto. (2017). Pelaksanaan proses pembelajaran Kurikulum 2013 SD Negeri 4 Krandegan. Jurnal Pendidikan Guru Sekolah Dasar Edisi 1 Tahun ke-6, ( 40)

Mulyasa, E. (2017). Pengembangan dan Implementasi Kurikulum 2013. Edisi V, Bandung: Remaja Rosdakarya.

Salim dan Syahrum. 2012. Metode Penelitian Kualitatif. Bandung: Citapustaka Media

Sugiyono. 2016. Metode Penelitian Kuantitatif, Kualitatif dan R\&D. Bandung: Alfabet.

Uddin, B, S \&Sobirin. 2017. Kebijakan Publik. Makssar: CV. Sah Media.

Ririn, S.D., Perangin-angin, R.B.B., and Mursid, R. (2020). Development of Multimultural PKN Interactive Learning Multimedia Development in Class IV SD IT NU Tanjung Morawa Academic Year 2018/2019. Budapest International Research and Critics in Linguistics and Education (BirLE) Journal Vol 3 (2): 845-853.

Simorangkir, F. M A., and Tanjung, D.S. (2019). Implementation of Multiple Intelligences Approach Based on Batak Angkola Culture in Learning Thematic For Class IV SD Negeri 100620 Pargarutan Julu South Tapanuli District. Budapest International Research and Critics in Linguistics and Education (BirLE) Journal Vol 2 (4): 547551.

Sugiharto (2020) Geographical students' learning outcomes on basic political science by using cooperative learning model with Group Investigation (GI) type in State University of Medan, Indonesia, Journal of Human Behavior in the Social Environment, 30:4, 447-456, DOI: 10.1080/10911359.2019.1696261. 